\title{
НАЛЕЖНА ПЕРЕВІРКА ЩОДО ПУБЛІЧНИХ ДІЯЧІВ: ЗАРУБІЖНИЙ ДОСВІД
}

\section{CUSTOMER DUE DILLIGENCE WITH RESPECT TO POLITICALLY EXPOSED PERSONS: FOREIGN EXPERIENCE}

\author{
Шевченко М. В. \\ доктор філософрії в галузі права \\ Університет митної справи та фрінансів \\ ORCID: 0000-0002-6708-016X \\ Mykhailo Shevchenko \\ Doctor of Philosophy in Law
}

За законодавством України первинний фрінансовий моніторине стосовно публічних діячів охоплює їх ідентифрікацію й верифікацію, погодження керівником суб'єкта первинного фрінансового моніторингу встановлення ділових відносин з публічними діячами або проведення їх порогових фрінансових операцій без встановлення ділових відносин, вживання достатніх заходів для встановлення джерела статків (багатства) та джерела коштів, а також постійний поглиблений моніторинг ділових відносин. Водночас, під час виконання пошукових та контрольно-аналітичних операцій для здійснення заходів, що охоплюються належною перевіркою публічних діячів, суб'єкти первинного фрінансового моніторингу діють самостійно, лише користуючись методологічною, методичною та іншою допомогою, яка, здебільшого, має характер абстрактних рекомендацій. За підсумками дослідження рекомендацій міжнародних організацій, приписів зарубіжного законодавства про запобігання та протидію відмиванню доходів, одержаних злочинним шляхом, у частині, що стосуються належної перевірки щодо публічних діячів, а також методичних роз'яснень, розроблених на виконання цих приписів, можна дійти висновку про те, що для підвищення ефективності законодавства України у цій сфрері, автор обгрунтовує висновок про те, що його слід доповнити положеннями: 1) щодо ідентифрікації та верифрікації публічних діячів - про вжиття державою заходів для приєднання до європейських глобальних ініціатив, спрямованих на формування публічних централізованих баз даних про публічних діячів, зокрема про персональний склад публічних діячів країни та про конкретні фрункції, які відповідно до національного законодавства вважаються важливими публічними фрункціями; 2) щодо встановлення джерела коштів публічного діяча, пов'язаних з фрінансовою операцією, та джерела статків (багатства) публічного діяча та постійного поглибленого моніторингу - про обов'язок спеціально уповноваженого державного органу розробити максимально деталізовані алгоритми дій, спрямованих на виконання цих заходів, із вказівкою на незалежні та достовірні джерела відомостей та контрольно-аналітичні інструменти, які можуть для цього використовуватись, з-поміж яких можуть бути розробка моделі майбутніх ділових відносин із публічним діячем (укладення угоди про порядок його обслуговування) та встановлення більш суворих операційних обмежень щодо фрінансових операцій публічних діячів. Ключові слова: ідентифрікація публічних діячів, інформаційне забезпечення суб'єктів первинного фрінансового моніторингу, належна перевірка щодо публічних діячів, публічний діяч, суб'єкти первинного фрінансового моніторингу.

Согласно законодательства Украины первичный фринансовый мониторинг относительно публичных деятелей охватывает их идентификацию и верификацию, согласование руководителем субъекта первичного фринансового мониторинга установления деловых отношений с публичными деятелями или проведения их пороговых фринансовых операций без установления деловых отношений, употребление достаточных мер для установления источника состояния (богатства) и источники средств, а также постоянный углубленный мониторинг деловых отношений. В то же время, при выполнении поисковых и контрольно-аналитических операций для осуществления мероприятий, охватываемых надлежащей проверкой публичных деятелей, субъекты первичного фринансового мониторинга действуют самостоятельно, пользуясь лишь методологической, методической и другой помощью, которая в основном имеет характер абстрактных рекомендаций. По итогам исследования рекомендаций международных организаций, предписаний зарубежного законодательства о предотвращении и противодействии отмыванию доходов, полученных преступным путем, в части, касающейся надлежащей проверки публичных деятелей, а также методических разъяснений, разработанных во исполнение этих предписаний, можно сделать вывод о том , что для повышения эфрфективности законодательства Украины в этой сфрере, автор обосновывает вывод о том, что его следует дополнить положениями: 1) касательно идентификации и верификации публичных деятелей - о принятии государством мер для присоединения к европейским әлобальных инициатив, направленных на фрормирование публичных централизованных баз данных о пу- 
бличных деятелей, в частности о персональном составе публичных деятелей страны и о конкретных фрунции, которые в соответствии с национальным законодательством считаются важными публичными функциями; 2) касательно установления источника средств публичного деятеля, связанных с финансовой операцией, и источники состояния (богатства) публичного деятеля и постоянного углубленного мониторинга - об обязанности специально уполномоченного государственного органа разработать максимально детализированные алгоритмы действий, направленных на выполнение этих мероприятий, с указанием на независимые и достоверные источники информации и контрольно-аналитические инструменты, которые могут для этого использоваться, среди которых могут быть разработка модели будущих деловых отношений с публичным деятелем (заключение соглашения о порядке его обслуживания) и установления более строгих операционных ограничений по фринансовым операциям публичных деятелей. Ключевые слова: идентификация публичных деятелей, информационное обеспечение субъектов первичного фринансового мониторинга, надлежащая проверка публичных деятелей, публичный деятель, субъекты первичного фринансового мониторинга.

According to the Ukrainian law, customer due diligence with respect to politically exposed persons covers their identification and verification, obtaining senior management approval for establishing or continuing business relationships with such persons; taking adequate measures to establish the source of wealth and source of funds that are involved in business relationships or transactions with such persons; conducting enhanced, ongoing monitoring of those business relationships. At the same time, when carrying out search and analytical operations while fulfilling duties covered by customer due diligence with respect to politically exposed persons, obliged entities are supposed to act self-sufficiently, using only methodological assistance, which by and large confines itself to abstract recommendations. Relying on the outcomes of research of recommendations of international organizations, the rules of foreign anti-money laundering statutes relating to customer due diligence with respect to politically exposed persons, as well as methodological explanations developed in pursuance of those rules, it can be concluded that in order to increase the effectiveness of Ukrainian anti-money laundering legislation in this part, the author substantiates that it should be supplemented with the following provisions: 1) regarding the identification and verification of politically exposed persons - on the implementing of measures by the Ukrainian government to join European global initiatives aimed at the formation of public centralized databases on politically exposed persons, in particular, identifying the personal composition of public figures of the particular country as well as specific functions that, in accordance with the national legislation, are considered important public functions; 2) regarding taking adequate measures to establish the source of wealth and source of funds that are involved in business relationships or transactions with such persons; conducting enhanced, ongoing monitoring of those business relationships - on the obligation of a financial intelligence unit to develop to the highest degree detailed algorithms of actions aimed at the performance of these duties, indicating independent and reliable sources of information and analytical tools that can be used for this, among which may be the development of a model of future business relations with a politically exposed person (securing an agreement on the procedure for their servicing) and the establishment of stricter operational restrictions on the financial transactions of public figures. Key words: identification of politically exposed persons, informational support of obliged entities, customer due diligence with respect to politically exposed persons, politically exposed persons, obliged entities.

Постановка проблеми у загальному вигляді та її зв'язок із важливими науковими чи практичними завданнями. Основоположним джерелом наповнення законодавства України про запобігання та протидію відмиванню доходів, одержаних злочинним шляхом, передовими організаційно-правовими механізмами є відповідний найкращий зарубіжний досвід. Зокрема, для визначення найбільш перспективних напрямів вдосконалення системи запобігання відмиванню доходів публічними діячами та подальшого опрацювання її теоретичного й методологічного підґрунтя особливе значення має виконання якісних порівняльно-правових дослідження відповідного кола питань. Серед іншого, це обумовлюється тим, що на цей час немає уніфікованих та універсальних підходів до розбудови та функціонування структур та процедур, покликаних унеможливити зловживання публічними діячами фінансовою системою, до чого вони вдаються для розширення можливостей безпечного розпорядження їх доходами корупційного походження та досягнення інших незаконних цілей. Натомість, має місце різ- номаніття законодавчих рішень у цій сфрері, окремі з яких, що функціонують, переважно, у правових системах розвинених держав, незважаючи на їх прогресивність, не знайшли своє відображення у відповідних положеннях вітчизняного законодавства, що значно стримує їх потенціал щодо запобігання відмиванню грошей публічними діячами на території України.

Аналіз останніх досліджень і публікацій, в яких започатковано розв'язання даної проблеми і на які спирається автор. Найбільш прогресивна на цей час думка вітчизняного наукового та фахового співтовариства з питань організаційно-правового забезпечення належної перевірки щодо публічних діячів суб'єктами первинного фінансового моніторингу відображена у виданих у 2021 році Державною службою фрінансового моніторингу України керівних настановах «Управління діловими відносинами із політично значущими особами», у яких викладено рекомендації, які за змістом та повнотою охоплення діяльності суб'єктів первинного фінансового моніторингу на виконання обов'язків зі вжиття 
заходів перевірки щодо публічних діячів не цілком відповідають найкращим зарубіжним практикам.

Виділення невирішених раніше частин загальної проблеми, котрим присвячується означена стаття. Стан наукового опрацювання питань запобігання та протидію відмиванню доходів, одержаних злочинним шляхом, публічними діячами не дозволяє констатувати те, що була приділена належна увага у контексті визначення оптимальних шляхів наближення до найкращих зарубіжних зразків законодавства України про запобігання та протидію відмиванню доходів, одержаних злочинним шляхом, у частині, яка стосується заходів належної перевірки, які застосовуються до публічних діячів та їх фінансових операцій.

Формулювання цілей статті (постановка завдання). Основним науковим завданням, на вирішення якого спрямовується стаття, є визначення рекомендацій міжнародних організацій, положень зарубіжного законодавства про запобігання та протидію відмиванню доходів, одержаних злочинним шляхом, у частині, що стосуються перевірки публічних діячів та їх фрінансових операцій, а також методичних роз'яснень, розроблених на виконання цих положень, запровадження яких у законодавство України може підвищити його ефрективність.

Виклад основного матеріалу дослідження. Першочерговим кроком для виконання зазначеного завдання $€$ фрормування уявлення про те, як здійснюється належна перевірка публічних діячів та їх фрінансових операцій, відповідно до вимог Закону України «Про запобігання та протидію легалізації (відмиванню) доходів, одержаних злочинним шляхом, фрінансуванню тероризму та фрінансуванню розповсюдження зброї масового знищення» (далі - Закон № 361-IX).

Насамперед, зазначимо, що згідно з приписами п. 34 ч. 1 ст. 1 та ч. 3 ст. 7 Закону № 361-ІХ у разі встановлення ділових відносин, наявності підозри, здійснення платіжних операцій без відкриття рахунка та за деяких інших обставин, визначених законом, здійснюється належна перевірка, яка охоплює:

- ідентифікацію та верифікацію клієнта (його представника) - отримання його ідентифікаційних даних, а також перевірка (підтвердження) належності йому цих ідентифікаційних даних;

- встановлення кінцевого бенефіціарного власника клієнта або його відсутності, у тому числі отримання структури власності з метою її розуміння, та даних, що дають змогу встановити кінцевого бенефріціарного власника, та вжиття заходів з верифрікації його особи (за наявності);

- встановлення (розуміння) мети та характеру майбутніх ділових відносин або проведення фрінансової операції;

- проведення на постійній основі моніторингу ділових відносин та фрінансових операцій клієнта, що здійснюються у процесі таких відносин, щодо відповідності таких фрінансових операцій наявній у суб'єкта первинного фрінансового моніторингу (далі - суб'єкта ПФМ) інформації про клієнта, його діяльність та ризик (у тому числі, в разі необхідності, про джерело коштів, пов'язаних з фінансовими операціями);

- забезпечення актуальності отриманих та існуючих документів, даних та інфрормації про клієнта [1].

При цьому, публічним діячам як одній з особливих категорій клієнтів у положеннях законодавства про запобігання та протидію відмиванню доходів, одержаних злочинним шляхом, приділяється особлива увага, яка виражається у запровадженні спеціальних правил їх ідентифрікації та моніторингу їх фрінансових операцій. Зокрема, для визначення належності клієнта або кінцевого бенефіціарного власника клієнта до політично значущих осіб, членів їх сімей або пов'язаних з ними осіб суб'єкт ПФМ має використати декілька надійних джерел інформації та вживати заходів для перевірки отриманої інфрормації (абз. 2 ч. 7 ст. 11 Закону № 361-IX). Також, законодавством встановлено, що під час здійснювати стосовно клієнтів, які (кінцеві бенефіціарні власники яких) $€$ політично значущими особами, членами їх сімей та особами, пов'язаними з політично значущими особами, зобов'язаний додатково до вищевикладених загальних заходів належної перевірки здійснювати такі заходи:

1) мати належну систему управління ризиками з метою виявлення фракту належності клієнта або кінцевого бенефріціарного власника клієнта до зазначеної категорії;

2) одержувати дозвіл керівника суб'єкта первинного фінансового моніторингу для встановлення (продовження) ділових відносин, проведення (без встановлення ділових відносин) фінансових операцій на суму, що дорівнює чи перевищує суму порогових фрінансових операцій;

3) вживати достатніх заходів з метою встановлення джерела статків (багатства) та джерела коштів, з якими пов'язані ділові відносини чи операції з такими особами;

4) здійснювати на постійній основі поглиблений моніторинг ділових відносин (ч. 13 ст. 11 Закону № 361-IX) [1].

Видаючи рекомендації щодо шляхів виконання цих обов'язків, Державна служба фрінансового моніторингу України (далі - Держфрінмоніторинг України) вказав на те, що використовувати системи управління ризиком при розпізнаванні PEP ceред клієнтів (відповідні питання, перевірка по базі даних, аналіз інформації, що знаходиться у відкритому доступі, і т.п.), а також обов'язковим має бути проведення перевірки статусу публічного дія- 
ча в ході оновлення інформації про своїх клієнтів. Джерела походження коштів, які особи надають СПФМ, мають підтверджуватися відповідними документами: наприклад, фінансовою звітністю, яка містить інформацію про види та розмір отриманих доходів, платіжними/ розрахунковими документами, що свідчать про отримані доходи за надані послуги, декларацією про доходи, документами про отриману спадщину, продаж майна, виплату страхової суми за договором страхування тощо. Крім того, державний регулятор рекомендує, поруч зі збільшенням частоти контрольних процедур і більш пильної уваги до публічних діячів, використовувати такі методи:

- контроль операцій - об'єднання інформації про клієнта, джерела його статків і джерела коштів з наступним аналізом факторів ризику та оцінкою того, наскільки динаміка операцій клієнта (стан його рахунку, обсяги транзакцій, види використовуваних інструментів тощо) співвідносяться з цими фракторами з урахуванням типологій діяльності корумпованих публічних діячів та інших методичних матеріалів від Держфінмоніторингу;

- отримання оновленої інформації про клієнта - регулярне оновлення клієнтського досьє публічного діяча завдяки збору інформації за допомогою автоматизованого пошуку по базах даних і ручного оновлення, або за допомогою контролю за операціями (ручного та (або) автоматизованого) [2, с. 104-105].

Більше того, стосовно іноземних публічних діячів, членів їх сімей та осіб, пов'язаних з такими політично значущими особами, а також клієнтів, кінцевими бенефеціарними власниками яких $€$ зазначені особи, за якими відповідно до ст. 7 Закону № 361-IX закріплюється високий ризик, мають вживатись посилені заходи, що передбачає, у тому числі збільшення частоти та обсягу дій з моніторингу ділових відносин та збору додаткової інформації щодо ділових відносин. Зокрема, передбачається необхідність для суб'єктів ПФМ, наскільки це можливо, проводити аналіз та вивчення підстав і цілей усіх фінансових операцій, які $€$ складними, незвично великими або такими, що проведені у незвичний спосіб або не мають очевидної економічної чи законної мети. Також, законом встановлений обов'язок підвищити ступінь і характер моніторингу ділових відносин з метою визначення, чи є такі фінансові операції або дії клієнта підозрілими (п. 49 ч. 1 ст. 1, ч. 3 ст. 12 Закону № 361-ІХ) [1].

Привертає увагу також й те, що здійснення фінансових операцій політично значущими особами, членами їх сім'ї та/або особами, пов'язаними з політично значущими особами, на суму, яка дорівнює чи перевищує 400 тисяч гривень та за деяких інших передбачених законом умов, $€$ ознакою, яка відносить їх до порогових та ви- значає необхідність здійснення щодо них заходів фінансового моніторингу (ч. 1 ст. 20 Закону № 361-IX) [1].

На доповнення до того, слід зауважити, що якщо політично значуща особа перестала виконувати визначні публічні фрункції, не менше ніж протягом 12 місяців мають враховуватись її триваючі ризики та здійснюються вищезазначені заходи, поки суб'єкт ПФМ не переконається в тому, що такі ризики відсутні. Поруч з тим, мають враховуватись ризики, що залишаються властивими політично значущій особі, зокрема:

- рівень впливу, що особа може ще мати;

- обсяг повноважень, якими вона була наділена;

- зв'язок між минулими та чинними повноваженнями тощо (ч. 13 ст. 11 Закону № 361-IX) [1].

Осмисливши вищевикладене, за законодавством України первинний фрінансовий моніторинг стосовно публічних діячів охоплює їх ідентифікацію й верифікацію, погодження керівником суб'єкта первинного фрінансового моніторингу встановлення ділових відносин з публічними діячами або проведення їх порогових фінансових операцій без встановлення ділових відносин, вживання достатніх заходів для встановлення джерела статків (багатства) та джерела коштів, а також постійний поглиблений моніторинг ділових відносин. Водночас, під час виконання пошукових та контрольно-аналітичних операцій для здійснення заходів, що охоплюються належною перевіркою публічних діячів, суб'єкти первинного фрінансового моніторингу діють самостійно, лише користуючись методологічною, методичною та іншою допомогою, яка, здебільшого, має характер абстрактних рекомендацій.

Натомість, взявши до уваги положення міжнародних документів та національних нормативноправових актів зарубіжних країн з питань запобігання та протидії відмиванню доходів, одержаних злочинним шляхом, та фінансуванню тероризму, а також ознайомившись із рекомендаціями щодо їх належного виконання, маємо підстави констатувати те, що в їх основі лежить прагнення забезпечити максимальне сприяння фінансовим установам та іншим суб'єктам ПФМ у здійсненні ними заходів належної перевірки стосовно публічних діячів, не обмежуючись встановленням формального обов'язку вживати цих заходів та наведенням орієнтовних джерел відомостей, які можуть бути корисними під час первинного фрінансового моніторингу

Насамперед, у деяких зарубіжних країнах визнається, що обов'язок встановлювати належність клієнта до публічних діячів суб'єкт ПФМ не може виконати виключно шляхом використання своїх власних ресурсів, через що належне інформаційне підґрунтя для ідентифікації публічних діячів 
та оцінки пов'язаних із ними ризиків утворюється за рахунок публічних централізованих баз даних про публічних діячів, що ведуться міждержавними утвореннями та окремими державами.

Офріційними відомостями суб'єкти ПФМ європейських країн забезпечуються за допомогою списку, що видається та має оновлюватись кожною країною-членом ЄС та вказує на конкретні функції, які відповідно до національного законодавства вважаються важливими публічними функціями для цілей положень законодавства про ВД/ФТ. Поруч із тим, держави мають звернутись до акредитованих на їх територіях міжнародних організацій за наданням списку важливих публічних функцій у межах цих міжнародних організацій. Більше того, встановлено, що кожен із цих списків спрямовується до Європейської Комісії, яка утворює на їх основі єдиний список та оприлюднює його (ст. 20а Директиви ЄС про відмивання доходів) [3].

Практика зосередження відомостей про публічних діячів (як національних, так і зарубіжних та міжнародних) у загальнодоступних джерелах поширена також у інших країнах. Зокрема, для потреб внутрішніх та зовнішніх користувачів відомостей про публічних осіб у Австралії вільно надається інформація, у тому числі про 1) імена та посади голів держав та урядів, міністрів закордонних справ, міністрів торгівлі та міністрів відповідальних за розвиток (список ведеться Департаментом закордонних справ і торгівлі Уряду Австралії); 2) суддів найвищих судів Австралії (список ведеться Судовим департаментом Генерального прокурора Австралії); 3) вищий офріцерський склад військовослужбовців Австралії (список ведеться Департаментом оборони Уряду Австралії); 4) державні підприємства та урядові організації Австралії (список ведеться Департаментом фрінансів Уряду Австралії) [4].

На доповнення до того, від суб'єктів ПФМ очікується звернення до інших загальних та спеціалізованих джерел відомостей про публічних діячів.

Утворення належного інформаційного підґрунтя у зарубіжних країнах забезпечується за рахунок вимоги до суб'єктів ПФМ під час ідентифікації публічних діячів брати до уваги інформацію:

- яка їм вже доступна, у тому числі здобута за результатами самостійного опитування клієнтів, моніторингу публікацій засобів масової інфрормації або під час здійснення інших заходів у межах господарської діяльності та знання працівників про події місцевого та більш глобального масштабу;

- з надійних загальнодоступних джерел: офіційних веб-сайтів компетентних органів іноземних країн, комерційних баз даних відповідного профрілю, публікацій засобів масової інформації із високим ступенем достовірності [5], перелік яких у деяких країнах визначається спеціально уповноваженим органом [6, с. 123,128$]$

Таким чином, оптимізація вітчизняного інфрормаційного інструментарію, що слугує основою для ідентифрікації публічних діячів суб’єктами ПФМ, може бути досягнута за рахунок приєднання до глобальних ініціатив $€ С$, а також доповнення європейських офріційних баз даних актуальними відомостями про українських публічних діячів. Також, корисним кроком за зразком зарубіжних країн може бути викладення у методичних рекомендаціях Держфінмоніторингу України конкретних та зрозумілих алгоритмів ідентифрікації публічних діячів із вказівкою на незалежні та достовірні джерела відомостей, що можуть для цього використовуватись.

Щодо джерела коштів, пов'язаних з фрінансовою операцією, та джерела статків (багатства) публічного діяча маємо підстави констатувати, що у зарубіжних країнах вони з'ясовуються за допомогою відомостей, одержаних від самого публічного діяча, а також шляхом відшукання та опрацювання даних із незалежних джерел.

Перш за все, слід взяти до уваги те, що конкретний комплекс заходів та їх інтенсивність визначаються у світлі конкретних обставин, насамперед, узгоджуючись із результатами оцінки суб'єктом ПФМ ризиків, пов'язаних з публічним діячем та його фінансовими операціями, однак, це не перешкоджає уповноваженим державним органам сприяти виконанню суб'єктами ПФМ відповідних обов'язків іншими способами, насамперед, шляхом забезпечення їх інформацією. Так, для полегшення регуляторного навантаження у зарубіжних країнах практикується створення державних джерел відповідних відомостей із одночасним спонуканням суб'єктів ПФМ до їх використання шляхом відображення цих джерел у профрільних рекомендаціях спеціально уповноважених органів. Прикладами того $є$ документи на веб-сторінках парламентів Сполученого Королівства (інформаційна довідка Палати громад Парламенту Сполученого Королівства про міністерські заробітні плати) [7] та Австралії (таблиця «Винагорода членів парламенту, посадових осіб парламенту та державних міністрів з 2011 року по цей час», складена Урядовою комісією Австралії з винагород) [8].

Вживши належних заходів із використанням вищезазначених джерел суб'єкт ПФМ має визначити подальший перебіг ділових відносин із публічним діячем. Особлива увага приділяється реагуванню суб'єкта ПФМ на його неспроможність або неможливість встановити джерела коштів, пов'язаних з фрінансовою операцією, та джерела статків (багатства) публічного діяча. За таких обставин суб'єкт ПФМ зобов'язаний розглянути питання про подання повідомлення про підозрілу фрінансову 
операцію та не встановлювати або припинити перебіг ділових відносин із публічним діячем [4].

Щодо постійного поглибленого моніторингу ділових відносин із публічними діячами, на безумовність якого вказують законодавства країн-членів $€ С$ та деяких зарубіжних країн, зазначимо, що аналіз нормативних джерел та рекомендаційних матеріалів спеціально уповноважених органів зазначених країн дозволяє визначити заходи, за допомогою яких у тих чи інших країнах із числа вищезазначених виконується обов'язок забезпечити постійний поглиблений моніторинг ділових відносин із публічними діячами. Такими заходами є:

а) з'ясування обставин особистого та профресійного життя публічного діяча (виконання ним важливих публічних фрункцій), що можуть вказувати на підвищений ступінь ризику, пов'язаного із обслуговуванням публічного діяча, зокрема:

- країна, у якій виконувались важливі публічні фрункції, із урахуванням її репутації з точки зору відповідності міжнародним стандартам загального стану публічного адміністрування, механізмів антикорупційного контролю та системи запобігання та протидії ВД/ФТ, а також поширеності інших незаконних явищ, у тому числі обіг наркотиків, порушення прав людини, фрінансування тероризму (для цього рекомендується використовувати звіти найбільш авторитетних профрільних міжнародних організацій);

- публічний діяч приховує свій статус;

- публічний діяч висловлює незвичну стурбованість або заперечення проти заходів посиленої належної перевірки щодо нього;

- обіг грошей за рахунком публічного діяча значною мірою не відповідає його відомим статкам (доходам та заощадженням)

- образ публічного діяча у засобах масової інформації дозволяє припускати його причетність до корупції або інших службових зловживань, відмивання злочинних доходів або фрінансування тероризму;

- ступінь фрактичної наближеності до публічного діяча (якщо клієнтом є член сім'ї публічного діяча або пов'язана із ним особа) [6, с. 125];

б) оновлення відомостей про публічних діячів із періодичністю 6 місяців (Китай) [9, с. 7]

в) розробка моделі майбутніх ділових відносин із публічним діячем для визначення показників, необхідних для контролю над відповідними фрінансовими операціями, у тому числі за допомогою угоди із публічним діячем із визначенням доступних послуг, прийнятних фінансових операцій та інших умов користування послугами суб'єкта ПФМ [10];

г) встановлення більш суворих операційних обмежень щодо фрінансових операцій (порогових значень, перевищення яких слугуватиме підста- вою для перевірки та/або попереднього їх погодження вищим керівництвом; інших особливих вимог) [11];

д) загальний моніторинг діяльності публічного діяча у межах ділових відносин із суб'єктом ПФМ із більшою частотою відповідно до графріка, у тому числі із залученням вищого керівництва до визначення долі таких ділових відносин;

е) посилений контроль за додатковими факторами ризику легалізації (відмивання) доходів, одержаних злочинним шляхом, та фрінансування тероризму, а у випадку виявлення таких додаткових фракторів ризику, якими є обставини, які свідчать про загрозу того, що операція спрямована на відмивання доходів або фрінансування тероризму, незалежно від того, чи є клієнт публічним діячем (неспроможність вказати на розумну мету фрінансової операції; значний обіг готівкових коштів; структурування операції таким чином, щоб уникнути обов'язкового фрінансового моніторингу; фрінансова операція є міжюрисдикційною, такою, що пов'язана із використанням складних корпоративних структур або такою, що сприяє анонімності, тощо) [4; 5].

Висновки. Таким чином, за підсумками дослідження рекомендацій міжнародних організацій, приписів зарубіжного законодавства про запобігання та протидію відмиванню доходів, одержаних злочинним шляхом, у частині, що стосуються належної перевірки щодо публічних діячів, а також методичних роз'яснень, розроблених на виконання цих приписів, можна дійти висновку про те, що для підвищення ефективності законодавства України у цій сфрері, його слід доповнити положеннями: 1) щодо ідентифікації та верифікації публічних діячів - про вжиття державою заходів для приєднання до європейських глобальних ініціатив, спрямованих на фрормування публічних централізованих баз даних про публічних діячів, зокрема про персональний склад публічних діячів країни та про конкретні функції, які відповідно до національного законодавства вважаються важливими публічними функціями; 2) щодо встановлення джерела коштів публічного діяча, пов'язаних з фінансовою операцією, та джерела статків (багатства) публічного діяча та постійного поглибленого моніторингу - про обов'язок спеціально уповноваженого державного органу розробити максимально деталізовані алгоритми дій, спрямованих на виконання цих заходів, із вказівкою на незалежні та достовірні джерела відомостей та контрольно-аналітичні інструменти, які можуть для цього використовуватись, з-поміж яких можуть бути розробка моделі майбутніх ділових відносин із публічним діячем (укладення угоди про порядок його обслуговування) та встановлення більш суворих операційних обмежень щодо фінансових операцій публічних діячів. 


\section{БІБЛІОГРАФІЧНИЙ СПИСОК:}

1. Про запобігання та протидію легалізації (відмиванню) доходів, одержаних злочинним шляхом, фрінансуванню тероризму та фрінансуванню розповсюдження зброї масового знищення : Закон України від 6 грудня 2019 року № 361-IX. Дата оновлення: 10 жовтня 2021 року. URL: https://zakon.rada.gov.ua/laws/card/361-20/ conv.

2. Державна служба фрінансового моніторингу України. Керівні настанови «Управління діловими відносинами із політично значущими особами». К., 2021. 141 с.

3. Про запобігання використанню фрінансової системи для відмивання грошей та фрінансування тероризму: Директива (ЄС) від 20 травня 2015 року 2015/849 Європейського парламенту та Ради ЄС, що вносить зміни до Регламенту (ЄС) № 648/2012 Європейського Парламенту та Ради і припиняє дію Директиви 2005/60/ЄС Європейського Парламенту та Ради і Директиви Комісії 2006/70/€C/. URL: http://www.sdfm.gov.ua/content/file/ Site_docs/2016/20160516/DIRECTIVE\%20(EU)\%202015_UA.htm.

4. Key terms used in the AML/CTF Rules definition of PEPs: Australian Transaction Reports and Analysis Centre Guidance of 21 December 2015. URL: http://www.austrac.gov.au/key-terms-used-amlctf-rules-definition-peps.

5. The Money Laundering, Terrorist Financing and Transfer of Funds (Information on the Payer) Regulations 2017: United Kingdom statute No. 692 coming into force on 26th June 2017. URL: http://www.legislation.gov.uk/ uksi/2017/692/pdfs/uksi_20170692_en.pdf.

6. Greenburg D.N., Roth J. (2011), Bank programs to interdict corruption-related money laundering. The Review of Banking \& Financial Services. 2011. Vol. 27. № 10. pp. 119-130. URL: https://www.Iw.com/thoughtLeadership/ bank-programs-interdict-corruption-related-laundering.

7. Ministerial Salaries: House of Commons Information Office Factsheet M6 of September 2010. URL: https:// www.parliament.uk/documents/commons-information-office/m06.pdf.

8. Remuneration of members of parliament, parliamentary office holders and ministers of state: Remuneration Tribunal Table of 2011. URL: http://www.aph.gov.au/ /media/05\%20About\%20Parliament/54\%20 Parliamentary\%20Depts/544\%20Parliamentary\%20Library/Research\%20Papers/2017-18/QuickGuides/QGParliamentaryRemuneration-Appendix.xls.

9. LexisNexis. Politically Exposed Persons (PEPs) and Customer Due Diligence in Asia - China, Hong Kong, Singapore and Malaysia. 2016. 17 p. URL: https://www.globalriskaffairs.com/wp-content/uploads/2016/10/LN_ AsiaPEPs_WP-3.pdf.

10. Guidance to Financial Institutions on Recent Events related to the Departure of Victor Yanukovych and Other Ukrainian Officials: Advisory guidance of United States Department of the Treasury FIN-2014-A001 of February 25, 2014. URL: https://www.fincen.gov/sites/default/files/shared/FIN-2014-A001.pdf.

11. Financial Transactions and Reports Analysis Centre of Canada (2017) Politically exposed persons and heads of international organizations - Financial entities. URL: http://www.fintrac-canafe.gc.ca/guidance-directives/clientclientele/Guide12/12-eng.asp.

\section{REFERENCES:}

1. On prevention and counteraction to legalization (laundering) of proceeds from crime, financing of terrorism and financing of proliferation of weapons of mass destruction : a statute of Ukraine of 6 December 2019 № 361-IX. Last amended: 10 October 2021. URL: https://zakon.rada.gov.ua/laws/card/361-20/conv. (in Ukrainian).

2. The State Financial Monitoring Service of Ukraine. Guidelines «Management of business relations with politically exposed persons». K., 2021. 141 p. (in Ukrainian).

3. Directive (EU) $2015 / 849$ of the European Parliament and of the Council of 20 May 2015 on the prevention of the use of the financial system for the purposes of money laundering or terrorist financing, amending Regulation (EU) No 648/2012 of the European Parliament and of the Council, and repealing Directive 2005/60/EC of the European Parliament and of the Council and Commission Directive 2006/70/EC. URL: http://www.sdfm.gov.ua/content/file/ Site_docs/2016/20160516/DIRECTIVE\%20(EU)\%202015_UA.htm. (in Ukrainian).

4. Key terms used in the AML/CTF Rules definition of PEPs: Australian Transaction Reports and Analysis Centre Guidance of 21 December 2015. URL: http://www.austrac.gov.au/key-terms-used-amlctf-rules-definition-peps.

5. The Money Laundering, Terrorist Financing and Transfer of Funds (Information on the Payer) Regulations 2017: United Kingdom statute No. 692 coming into force on 26th June 2017. URL: http://www.legislation.gov.uk/ uksi/2017/692/pdfs/uksi_20170692_en.pdf.

6. Greenburg D.N., Roth J. (2011), Bank programs to interdict corruption-related money laundering. The Review of Banking \& Financial Services. 2011. Vol. 27. № 10. pp. 119-130. URL: https://www.Iw.com/thoughtLeadership/ bank-programs-interdict-corruption-related-laundering.

7. Ministerial Salaries: House of Commons Information Office Factsheet M6 of September 2010. URL: https:// www.parliament.uk/documents/commons-information-office/m06.pdf.

8. Remuneration of members of parliament, parliamentary office holders and ministers of state: Remuneration Tribunal Table of 2011. URL: http://www.aph.gov.au/ /media/05\%20About\%20Parliament/54\%20 Parliamentary\%20Depts/544\%20Parliamentary\%20Library/Research\%20Papers/2017-18/QuickGuides/QGParliamentaryRemuneration-Appendix.xls.

9. LexisNexis. Politically Exposed Persons (PEPs) and Customer Due Diligence in Asia - China, Hong Kong, 
Singapore and Malaysia. 2016. 17 p. URL: https://www.globalriskaffairs.com/wp-content/uploads/2016/10/LN_ AsiaPEPs_WP-3.pdf.

10. Guidance to Financial Institutions on Recent Events related to the Departure of Victor Yanukovych and Other Ukrainian Officials: Advisory guidance of United States Department of the Treasury FIN-2014-A001 of February 25, 2014. URL: https://www.fincen.gov/sites/default/files/shared/FIN-2014-A001.pdf.

11. Financial Transactions and Reports Analysis Centre of Canada (2017) Politically exposed persons and heads of international organizations - Financial entities. URL: http://www.fintrac-canafe.gc.ca/guidance-directives/clientclientele/Guide12/12-eng.asp. 